\title{
Hérnia discal: Procedimentos de tratamento
}

\author{
Disc Herniation: Treatments Process
}

WILSON FÁBIO NEGRELU

\section{RESUMO}

A hérnia de disco é um processo em que ocorre a ruptura do anel fibroso, com subsequente deslocamento da massa central do disco nos espaços intervertebrais. É considerada uma patologia extremamente comum, que causa séria inabilidade em seus portadores. Estima-se que 2 a $3 \%$ da população sejam acometidos desse processo, cuja prevalência é de 4,8\% em homens e 2,5\% em mulheres, acima de 35 anos. São fatores de risco, causas ambientais, posturais, desequilíbrios musculares e possivelmente, a influência genética. A terapia conservadora tem sido a preferida como a primeira escolha de tratamento, cujos objetivos são o alívio da dor, o aumento da capacidade funcional e o retardamento da progressão da doença. Nesta revisão, são abordadas as principais metodologias, de acordo com a literatura, dando ênfase ao uso de fármacos analgésicos e anti-inflamatórios, o uso de órteses, a acupuntura, o repouso e a adoção de um programa de exercícios adequados.

Descritores: hérnia de disco; lombociatalgia; tratamentos.

\section{INTRODUÇÃO}

A hérnia de disco é uma freqüente desordem músculo esquelética, responsável pela lombociatalgia. A expressão hérnia de disco é usada como termo coletivo para descrever um processo em que ocorre ruptura do anel fibroso, com subsequente deslocamento da massa central do disco nos espaços intervertebrais, comuns ao aspecto dorsal ou dorso- lateral do disco (Barros et al. , 1995) ${ }^{7}$. Os problemas oriundos dessa afecção têm sido as razões mais freqüentes de dispensa do trabalho por incapacidade (Atlas et al., 2000) . $^{4}$.

Esse processo ocorre mais freqüentemente em pacientes entre 30 e 50 anos, embora possa também ser encontrado em

\section{SUMMARY}

The disc herniation is a process where the fibrous ring disrupts, with subsequent central disc mass dislocation. It is considered a extremely common pathology, which causes disability. It is estimated that 2 to $3 \%$ of the population have taken with this process whose prevalence is $4.8 \%$ in males and $2.5 \%$ in female, over 35 years old. Environmental causes, posture, muscular imbalance and possibly genetic influence have been considered as risk factors. The conservative therapy has been preferred as the first choice treatment, aiming pain relief, increase of functional capacity and avoidment of disease progression. In this review, it is approached the main methodologies, according to the literature, focusing on drugs prescriptions, orthesis indication, acupunture, rest and a suitable exercise program.

Key Words: disc herniation; low back pain, treatments.

\section{INTRODUCTION}

Disc herniation is a frequent musculo-skeletal disorder responsible for low back pain. This expression is commonly used to describe a process where the fibrous ring disrupts, with subsequent central disc mass dislocation (Barros et al., 1995)? The problems arising from that affection have been the most frequent reasons concerning work dismissal and disability compensation claims (Atlas et al., 2000)4.

This process occurs usually in patients between 30-50 years old, although it can be found in elderly people, teenagers and rarely in children (Garrido, 1993; Mayer et al., 1996; Obukhov et al., 1996; Bortolleto et al., 1998)27:45;47:16. The disc herniation is considered a

Ortopedista e Traumatologista 
adolescentes e pessoas idosas e mais raramente em crianças (Garrido, 1993; Mayer et al.,1996; Obukhov et al.,1996; Bortolleto et al., 1998) ${ }^{27: 45 ; 47: 16}$. A hérnia de disco é considerada uma patologia extremamente comum, que causa séria inabilidade em seus portadores e em vista disso, constitui um problema de saúde pública mundial, embora não fatal (Long et al.,1996) ${ }^{37}$. Estima-se que 2 a 3 \% da população sejam acometidos desse processo, cuja prevalência é de 4,8\% em homens e 2,5\% em mulheres, acima de 35 anos. A idade média para o aparecimento do primeiro ataque é aproximadamente 37 anos, sendo que em $76 \%$ dos casos há antecedente de uma crise lombar, uma década antes (Bell et al., 1984; Della-Giustina, 1999) ${ }^{11 ; 21}$.

Um número de fatores de risco ambiental tem sido sugerido, tais como hábitos de carregar peso, dirigir e fumar, além do processo natural de envelhecimento (Urban \& Roberts, 1995) ${ }^{58}$. No entanto, em estudo retrospectivo, realizado por Battie et al. $(1995 b)^{10}$, esses fatores mostraram efeitos modestos no aparecimento da herniação, resultados esses que reforçam a teoria de que a etiologia de tal afecção pode ser explicada com base na influência genética, achados esses corroborados por outros autores (Varlotta et al., 1991; Scarpinelli, 1993; Matsui et al.,1992; Battie et al. , 1995a; b; Urban \& Roberts, 1995, Matsui et al., 1998; Sambrook et al., 1999) 59;52;43;9;58:44;51.

Há indícios outros que apontam para a confirmação da herança genética como componente importante na etiopatogênese da hérnia discal. Recentemente, vários esforços têm sido empreendidos na tentativa de identificar genes que desempenham papel relevante no desenvolvimento e evolução dessa patologia (Battie et al.,1995a) ${ }^{9}$. Dentre os possíveis envolvidos parecem figurar o gene receptor da vitamina D, VDR (Jones et al.,1998; Videman et al.,1998) $)^{31 ; 60}$, o gene que codifica para uma das cadeias polipeptídicas do colágeno IX, ou seja, o gene COL9A2 (Annunen et al. ,1999) ${ }^{3}$ e o gene "aggrecan" humano (AGC), responsável pela codificação do proteoglicano, maior componente protéico da cartilagem estrutural, que suporta a função biomecânica nesse tecido (Doege et al., 1997; Horton et al., 1998; Kawaguchi et al. , 1999) $)^{23 ; 30 ; 33 . ~}$

A dor que acompanha e caracteriza a hérnia de disco é geralmente causada por herniação, degeneração do disco e por estenose do canal espinal (Magnaes, 1999) ${ }^{40}$. Contudo, esses processos, por si só, não são responsáveis pela dor e, portanto, devem ser também contabilizadas a compressão mecânica e as mudanças inflamatórias ao redor do disco e da raiz do nervo (Cortet \& Bourgeois, 1992) ${ }^{20}$.

As desordens músculo- esqueléticas estão entre as mais comuns condições em que o paciente necessita alívio (Borenstein, 1993; Bullock et al. , 1999) ${ }^{14 ; 18}$ e na medicina ocidental, a terapia conservadora tem sido a preferida como a primeira escolha na grande maioria dos casos (Deyo, 1983; Bell \& Rothman, 1984; Revel, 1994; Komori et al.,1996; 1998; Zentner et al., 1997) 22;11;50;3;;34;69, embora a opção de tratamento seja ainda uma questão em aberto (Herno et al., 1996) ${ }^{28}$. Três são os objetivos desse tratamento, quer sejam, o alívio da dor, o aumento da capacidade funcional e o retardamento da progressão da doença (Borenstein, 1997) ${ }^{15}$ common, serious disabling and non-fatal pathology and therefore a health problem worldwide (Long et al., 1996) ${ }^{37}$. It has been estimated that 2 to $3 \%$ of the entire population have taken with this process whose prevalence is $4.8 \%$ in males and $2.5 \%$ in female, over 35 years old. The mean age for the first attack is 37 years old approximately and $76 \%$ from all cases have a preceding low back crisis, 10 years before (Bell et al., 1984; Della-Giustina, 1999) ${ }^{11 ; 21}$.

A number of environmental risk factors have been suggested, such as lifting, driving and smoking besides the aging natural process (Urban \& Roberts, 1995) ${ }^{58}$. Nevertheless, in a retrospective study carried on by Battie et al.(1995b) ${ }^{10}$ these factors showed a modest effect which reinforced the ethiological theory for disc herniation based on genetic influences (Varlotta et al., 1991; Scarpinelli, 1993; Matsui et al., 1992; Battie et al., 1995 a; b; Urban \& Roberts, 1995; Matsui et al., 1998; Sambrook et al, 1999) 59;52;43;9;58;44;51.

There are other indicative contribution to confirm the genetic inheritance as a important component in the ethiopathogenesis of disc herniation. Recently, a lot of effort has been undertaken aiming the identification of genes that play a relevant role in the development and evolution of this pathology (Battie et al., 1995 a) ) $^{9}$. Amongst them, it seems to participate the vitamin $D$ receptor gene, VDR (Jones et al., 1998; Videman et al., 1998) ${ }^{31 ; 60}$, the gene that codifies for one of polipeptidic collagen chain, COL9A2 (Annunen et al., 1999) ${ }^{3}$ and the human aggregan gene, a major component of articular cartilage and supports the biomechanical function of this tissue (Doege et al., 1997; Horton et al., 1998; Kawaguchi et al., 1999)23;30;33.

The pain that characterizes disc herniation is caused by disc herniation and degeneration and by spinal canal stenosis, as well (Magnaes, 1999) ${ }^{40}$. However, they are not on their own responsible for the process, therefore it has to be account for the mechanical compression and the inflammatory changes around the disc and the nerve root (Cortet \& Bourgeois, 1992) ${ }^{20}$.

The musculo-skeletal disorders are one of the commonest condition where the patient seeks after relief (Borenstein, 1993; Bullock et al.,1999) ${ }^{14 ; 18}$ and the western medicine offers the conservative treatment as the first choice in the majority of cases (Deyo, 1983; Bell \& Rothman, 1984; Revel, 1994; Komori et al., 1996;1998; Zentner et al., 1997)22;11;500;35;34;69, although the treatment option relies an open question still (Herno et al., 1996) ${ }^{28}$. Three are the objectives of the conservative treatment, i.e., the pain relief, the function capacity improvement and the disease progress delay (Borenstein, 1997) ${ }^{15}$.

The conservative treatment meaning is to impose to the patient relative or complete low back immobilization associated with different auxiliary methodologies such as belts and corsets, manipulation, physical activities program, traction, criotherapy, pain killer prescription and acupunture.

In 1956, after studying different features of consenvative method, Söderberg affirmed that the real therapeutically value of this treatment is the absolute rest in conjunction with corset use. Afterwards, this assumption was correlated by Armnstrong in 1965 that postulated different degrees for immobilization, ranging from relative to rigorous rest where the patient is forbidden to sit aiming to avoid movements that can generate dorsal tension (Ref. em Kakelius, 1970) ${ }^{32}$.

Besides those data, there is sufficient information electing this practice as a safe method leading good results, once the horizontal 
Entende-se por tratamento conservador a imposição, ao paciente, de relativa à completa imobilização da região lombar em associação com diferentes metodologias auxiliares, como o uso de cintos e coletes, a manipulação, o programa de atividade física, a tração, a crioterapia, a acupuntura e a prescrição de analgésicos e anti-inflamatórios.

Após estudar diferentes modalidades de métodos conservadores, Söderberg afirmou, em 1956, que somente a imobilização assegurada pelo repouso absoluto e auxiliada pelo uso de colete pode ser encarada como tratamento de real valor terapêutico. Anos após, Armstrong (1965) corroborou com essa assertiva, postulando além disso, que a imobilização pode ter graus variados, desde intensidade relativa até o rigoroso repouso, situação em que o paciente fica proibido de sentar-se, objetivandose, nesse caso, evitar-se certos movimentos que gerem tensão dorsal (Referências em Kakelius, 1970) ${ }^{32}$.

Além desses dados, há também suficiente informação que elege essa prática como um método seguro na obtenção de bons resultados, uma vez que a posição horizontal alivia a dor irradiada em muitos pacientes (Palazzo \& Kahn, 1992; Christensen et al., 1993; Weber, 1994; Zentner et al. , 1997) 48;19;65;69.

É importante salientar que, apesar do repouso ser amplamente indicado nesses processos patológicos, não há resultados conclusivos sobre seus benefícios. O período de repouso deve estender-se o suficiente para proporcionar a redução do processo inflamatório (Vroomen et al.,1999)62, em razão dos efeitos colaterais decorrentes da inatividade prolongada, desse modo a volta à mobilidade deve ocorrer, de forma gradual, uma semana após o início (Ernst \& Fialka, 1993a) ${ }^{24}$. A indicação de coletes e cintos durante o repouso é incerta, pois é somente recomendada como forma de imobilização parcial em dores específicas (Ernst \& Fialka, $1993 b)^{25}$.

A manipulação, ou seja, movimentos passivos abruptos da vértebra além de seu limite fisiológico, mas dentro do limite anatômico, é vista com cautela, dado que esse método mais agressivo não tem demonstrado abreviar o curso da enfermidade, nem tampouco reduzir a morbidade (Young et al.,1997) ${ }^{68}$. O mecanismo de ação da manipulação não é bem entendido, no entanto teorias atuais propõem que a dor provém de um desequilíbrio da atividade muscular, que através da ação reflexiva, a manipulação pode aliviar (Fiechtner \& Brodeur, 2000) ${ }^{26}$. Embora ainda permaneçam dúvidas sobre a adoção da terapia auxiliar de manipulação, há indicações de seu uso antes de se decidir pelo procedimento cirúrgico (Bergmann \& Jongeward, 1998) ${ }^{12}$.

Os princípios e benefícios de exercícios apropriados são bem conhecidos e a motivação do paciente para executar atividade física é geralmente maior durante duas a três semanas após o período de inabilidade. Se, no entanto houver recorrência da enfermidade, os exercícios deverão ser descontinuados e reiniciados somente após a remissão dos sintomas. Esse programa deve incluir exercícios de flexibilidade e alongamento, com aumento gradual em sua execução (AAOS, 1996; Ulreich \& Kullich, 1999) ${ }^{1 ; 57}$. O efeito da terapia não parece ser devido à reversão da debilidade física, mas sim a algum efeito central, envolvendo provavelmente um ajustamento de percepção em relação à dor e incapacidade (Mannion et al., 1999) ${ }^{42}$. position relieves the radiated pain in a lot of patients (Palazzo \& Kahn, 1992; Christensen et al., 1993; Weber, 1994; Zentner et al., 1997) $48 ; 19 ; 65 ; 69$.

Despite the rest indication it has to be point out that there is no conclusive results concerning its benefits. The rest length has to be just sufficient to provide reduction of the inflammatory process (Vroomen et al., 1999) ${ }^{62}$, according to the side effects arose from the inability. Therefore, one week after rest onset it has to be set the mobility return (Ernst \& Fialka, 1993a) ${ }^{24}$. The corset and belt indication is recommended as a partial inability in specific pain due to its uncertain utility (Ernst \& Fialka, 1993b) ${ }^{25}$.

The manipulation is faced with caution once there is no improvement demonstration regarding disease shortening or morbidity reduction neither (Young et al., 1997) ${ }^{68}$. The manipulation mechanism action is not well understood, however current theories propose that pain is due to a unbalanced muscle activity that manipulation can relieve through a reflexive action (Fiechtner \& Brodeur, 2000 ${ }^{26}$. Although it remain doubts around the adoption of manipulation as a auxiliary therapy, its indication is accepted before deciding for the surgery (Bergmann \& Jongeward, 1998) ${ }^{12}$.

The principle and benefit of appropriate physical activities are well known and usually the patient motivation for it is better during or two or three weeks after the inability period. If any recurrence occurs the program must be discontinued to be reinitiated after the remission symptoms. The physical program should include flexibility and stretching exercises with gradual increase in its execution (AAOS, 1996; Ulreich \& Kullich, 1999)1;57. The therapy effect does not seem to be due to the physical inability reversion but to a central effect involving a perception adjustment regarding inability and pain (Mannion et al., 1999) ${ }^{42}$.

Concerning the traction application there is no conclusive result focused on pain relief, spine mobility or neurological signs. However, the self-traction, where the patient executes the traction by itself has shown more suitable results compared to the rest and corset employment.

The criotherapy seems to have some effect on muscular spasm, once the ice-elicited vasoconstriction reduces hyperemia, promoting a reflexive compensatory peripheral vasodilatation. The heat is a physical auxiliary approach in the treatment of pain as well and it can be superficial, applied through heating bag or with the employment of short waves and ultra sound. Nevertheless, it has to be aware concerning burns caused by local anesthesia and hypo-anesthesia. The use of deep heat is refuted in patients with tumors, metallic implants, in pregnant women, children, in infection process and gonad organs.

Regarding pain killer prescription, they are necessary once the rapid relief of peripheral pain is able to prevent the evolution to the chronic status, besides being an adjuvant to maintain the patient in rest (Ernst \& Fialka, 1993b) ${ }^{25}$. The muscle relaxants are prescribed and they are useful for patients with severe para vertebral muscle spasm. The morphine and related drugs should be avoided, although its usefulness in very severe symptoms. They can be replaced by psychoactive drugs that are indicatives for patients presenting chronic pain complicated by an anxious and depressive component. The anesthetic drugs has shown good results, as well (MedrickGoldberg et al., 1999) ${ }^{46}$. 
Os resultados obtidos com a aplicação da tração não têm demonstrado efeitos positivos no alívio da dor, na mobilidade da espinha ou nos sinais neurológicos. Todavia a auto- tração, método em que o paciente executa por si mesmo a tração, tem conferido respostas mais eficazes em comparação ao uso de coletes e repouso.

A crioterapia parece, por sua vez, ter algum efeito sobre o espasmo muscular, dado que a vaso- constrição provocada pelo gelo reduz a hiperemia, promovendo ao mesmo tempo, a vasodilatação periférica compensatória reflexa. O calor também é uma medida física auxiliar no tratamento da dor e pode ser superficial, efetuado por meio do uso de bolsa térmica, ou profundo com o emprego de ondas curtas e ultra-som. No entanto, cuidados devem ser tomados na tentativa de se evitar queimaduras decorrentes da anestesia e hipoestesia locais. O uso do calor profundo é contra-indicado em pacientes com tumores, implantes metálicos e marca- passos, em gestantes, nos processos infecciosos supurativos, sobre órgãos gonadais e em crianças.

Com relação à prescrição de analgésicos, pode-se dizer que os mesmos são necessários, uma vez que o alívio rápido da dor periférica é capaz de prevenir a evolução para o estado crônico, sendo também um coadjuvante útil para manter o paciente em repouso (Ernst \& Fialka, 1993b) ${ }^{25}$. Os relaxantes musculares são usados, sendo úteis em pacientes com severo espasmo muscular para- vertebral, porém devem ser empregados por curto período. A morfina e outras drogas que induzem dependência devem ser evitadas, embora possam ser indicadas em casos extremos. No lugar delas, podem ser administradas drogas psico- ativas, indicadas nos casos de pacientes com dor crônica complicada por um componente de ansiedade e depressão, bem como o uso de anestésicos que têm demonstrado boa resposta (MedrickGoldberg et al., 1999) ${ }^{46}$.

Por ser a hérnia de disco uma síndrome de dor neuropática, causada por compressão e/ou inflamação da raiz nervosa espinal, seu tratamento não prescinde de anti-inflamatórios não hormonais, empregados como primeira instância (Viton et al.,1998; Bratton, 1999) 64:17. Em caso de insucesso são substituídos pelos hormonais. Por outro lado, a injeção epidural de esteróides e a infiltração peri-radicular são recomendadas por alguns pesquisadores, apesar da literatura científica apresentar resultados conflitantes (Hopayian \& Mugford, 1999) ${ }^{29}$.

A acupuntura tem apresentado bons resultados, uma vez que seu efeito parece estar relacionado à liberação de vários neurotransmissores que, por sua vez inibem ou excitam as sinapses (Yamamura et al., 1995) ${ }^{67}$, proporcionando significante melhora dos sintomas apresentados em curto espaço de tempo (Bullock et al. , 1999) ${ }^{18}$. Em vista dos resultados promissores que têm sido obtidos com o uso da acupuntura no alívio da dor, há a sugestão de se explorar mais seu uso (Longworth \& Mc Carthy, 1997) ${ }^{38}$.

Além dessas, muitas outras propostas alternativas de tratamento têm surgido, no entanto não há suficiente suporte de estudos científicos, havendo como conseqüência um crescimento lento dessa área. A execução de tentativas clínicas é difícil, com a agravante de demandar extrema habilidade, honestidade e neutralidade do pesquisador.
The disc herniation is a neuropathic pain syndrome caused by spinal root compression or inflammation and its treatment demands the prescription of non-hormonal anti-inflammatory drugs at the first instance

(Viton et al., 1998; Bratton, 1999) ${ }^{64 ; 17}$. When this prescription is not well succeeded it can be replaced by the hormone ones. On the other hand, the epidural steroid application and the peripheral radicular infiltration are recommended by some researchers, despite the conflicting literature data (Hopayian \& Mugford, 1999) ${ }^{29}$.

The acupuncture has been presenting good results and its benefit is related with neurological signal that inhibit or excite the synapses (Yamamura et al., 1995) ${ }^{67}$, providing significant symptoms enhancement in a short period of time (Bullock et al., 1999) ${ }^{18}$. In according of that, there is a suggestion to inquire more about this method (Longworth \& Mc Carthy, 1997) ${ }^{38}$. Other alternative proposal of conservative treatment has emerged, despite the lack of scientific research which generates a slow improvement of this area of expertise. The clinic trial execution is difficult due to the extreme ability, honesty and neutral performance of the researcher.

A lot of drawbacks must be solved having in mind as a ultimate goal to carry on the research in the most adequate way, in order to generate dependable information. For instance, it can be cited how to select homogeneous material, how to perceive the morphological and pathological conditions, how to register the pain and how to effectuate the acceptable protocols concerning the match among the individuals belonging to the study (Bessette et al., 1996) ${ }^{13}$. At the same time, the knowledge of psycho-social conditions are fundamental, seeking for the participants cooperation in order to better execute the research and to elucidate the results (Waddell, 1992; Bach, 1998) $)^{63 ; 6}$.

The ethical aspect regarding intentionally placebo use has to be considered, since its effect will be involved in the treatment of the patients, whether approved or not.

The surgery practice is another available option for the disc herniation treatment, although its indication occurs when the natural course of the disease worsens after the employment of nonaggressive measures. The exact point when it can be concluded that the conservative treatment failed is controversial and it varies from one individual to another, depending on the symptoms severity, the social and economic circumstances of the patients and on the relationship between the patient and the physician as well (Schiltenwolf, 1999) ${ }^{53}$. This point detection is considered a challenge for the knowledge and experience of the medical profession. In cases that are not clear, it has to do further investigations, such as the spine fluid protein content and the fibrinolitic activity to clarify and conduct to a better decision. Definitive surgery indication are the cauda equina syndrome, unbearable pain and progressive muscle weakening. In other cases, the indication is relative and depends essentially on the duration of symptoms; the vertebral foramen or canal stenosis and the quality or severity of symptoms. The motor or sensorial deficit do not account for surgery because the chances of recovery are similar either applying the conservative or surgical treatment as well.

There are no much data comparing the efficacy between conservative and surgical treatments. One of the reason is due to the lack of study standardization regarding patient samples, 
Muitos entraves precisam ser solucionados, a fim de se conduzir adequadamente a pesquisa científica, que gerará informações confiáveis. Dentre esses, tem-se, por exemplo, o modo de como deve proceder-se à seleção de material homogêneo, ao conhecimento das condições pato- morfológicas, ao registro da dor, bem como a maneira de se efetuarem os protocolos aceitáveis de pareamento entre os indivíduos que compõem o estudo (Bessette et al., 1996) ${ }^{13}$. Do mesmo modo, é fundamental a análise das condições psico- sociais e constitucionais dos indivíduos pertinentes ao estudo, de modo a procurar sua cooperação para a execução do trabalho e melhor esclarecimento dos resultados (Waddell, 1992; Bach, 1998) ${ }^{63 ; 6}$.

O aspecto ético de se usar placebo intencionalmente é algo a ser considerado, pois se aprovado ou não, tal efeito sempre estará envolvido no tratamento de pacientes.

O procedimento cirúrgico é a outra opção disponível para o tratamento da hérnia discal, embora sua indicação ocorra quando o curso natural do processo em questão segue uma piora significativa após o uso de medidas não agressivas. O exato ponto em que se conclui que houve falha na aplicação de medidas conservadoras é controverso e pode variar consideravelmente de um indivíduo para o outro, dependendo da severidade dos sintomas e das circunstâncias social e econômica dos pacientes, bem como de sua relação com médico (Schiltenwolf, 1999) ${ }^{53}$. Detectar esse ponto crucial constitui verdadeiro desafio para o conhecimento e experiência do profissional médico. Em casos questionáveis, investigações adicionais incluindo nível de proteína do fluido espinal e exame da atividade fibrinolítica podem esclarecer e conduzir a uma melhor decisão. Indicações definitivas de cirurgia são a síndrome da cauda eqüina, dor insuportável e progressivo enfraquecimento muscular. Em outros casos, a indicação é relativa e depende essencialmente da duração dos sintomas; da estenose do canal vertebral ou foramen e da qualidade e severidade dos sintomas. A presença isolada de déficit motor ou sensorial não é indicação para cirurgia, visto que as chances de recuperação são semelhantes, tanto com a aplicação do tratamento conservador como do cirúrgico.

Poucos estudos existem comparando a eficácia entre os tratamentos conservador e cirúrgico. Uma das causas reside no fato de que não há uniformização nos estudos realizados, com relação ao diagnóstico, composição da amostra de pacientes, delineamento experimental e uniformização de critérios que meçam os resultados. A seleção apropriada de pacientes, bem como a combinação do diagnóstico claro sobre a raiz do nervo afetado e os achados patológicos correspondentes parecem ser a condição mais importante para o sucesso da cirurgia (Magnaes, 1999) ${ }^{40}$. Pacientes que demonstram boa expectativa quando optam por esse procedimento apresentam recuperação mais rápida (Lutz et al., 1999) ${ }^{39}$, razão pela qual a decisão pela cirurgia deva ser comungada entre médico e paciente.

Dentre os estudos comparativos, Kakelius (1970) ${ }^{32}$ acompanhou pacientes tratados de modo conservador e cirúrgico por um período de 7 anos e 4 meses. No início, os resultados mais promissores foram encontrados entre aqueles submetidos à cirurgia, no entanto após 6 meses nenhuma diferença significativa experimental design and criteria patterns that can measure the results. The appropriated patient selection and the combination of a clear affected nerve root diagnosis allied with a correspondent pathologic findings as well seem to be the most important condition leading to the surgery success (Magnaes, 1999) ${ }^{40}$. Patients who demonstrate good expectation at the surgery option moment present a more rapid recovery (Lutz et al., 1999) ${ }^{39}$, reason why the surgery has to be decided both for the patient and the physician.

Amongst the comparative studies performed, Kakelius (1970) ${ }^{32}$ followed up patients treated in a conservative and surgical way during 7 years and 4 month. At the first beginning, the best results were encountered among the patients that underwent surgery, however 6 months later no significant difference was observed between both groups. Those data suggest a transitory condition for disc herniation and the solution is independent of the applied methodology. Similar results were found by Weber (1983) ${ }^{64}$ that showed a significant recovery after one year in patients that underwent surgery. Nevertheless, this significance becomes similar comparing to conservative treatment after 4 years and no difference was observed after 10 years.

The benefits confront between conservative and surgical treatment was approached in a prospective study conducted by Atlas et al. (1996) ${ }^{5}$. Although the symptoms overlap between conservative and surgical treatment, the patient treated by the last method reported significant enhancement after one year. However, effects concerning compensatory employment and work were similar in both groups. No difference was observed among patients that underwent surgery and those presenting mild symptoms treated in a conservative way.

Overall, the comparative studies keep unaltered the conservative treatment efficacy (Zentner et al. 1997; Simotas et al., 2000)69;54, besides it can be extended over 8 weeks, due to denoted patient progressive recovery. This decision places the conservative treatment as an allied in the surgery postponement. Therefore, the surgery has to be considered when the conservative treatment does not demonstrate efficacy anymore (Kurth et al., 1996; Postacchini, 1996; Stevens et al., 1997) $36 ; 49 ; 56$.

Complete disc herniation absorption data (Basile et al., 1993; Song et al., 1999):55 reinforce the indication of consenvative treatment. At the same time, there are positive results (Ahn et al., 2000) ${ }^{2}$ of conservative treatment concerning decrease in size of transligamentous herniations (posterior longitudinal ligament).

Nowadays, facing the new scenario involving health insurance plan, all the high cost elective surgery has to be revised, being the disc herniation surgery a proper example of that (Stevens et al., 1997) ${ }^{56}$. According to Malter \& Weinstein (1996) ${ }^{41}$ the study results from cost-benefit are inconsistent, although if the long term benefit are considered, the surgery does not demonstrate to be more effective than the conservative treatment.

The variety of expert opinions and the lack of a systematic methodology hamper the development of reliable clinical guides to be used promptly. There is also the need of elaborating standardized protocols in order to quantify, to compare and to summarize different expert judgements about the best treatment to be adopted (Wietlisbach et al., 1999)66. 
foi observada entre os dois grupos de pacientes. Esses dados sugerem que a hérnia discal é uma condição transitória, cuja solução ocorre independentemente do método aplicado. Resultados similares foram obtidos por Weber $(1983)^{64}$, com significativa melhora no grupo de pacientes operados após o primeiro ano, em comparação ao grupo submetido ao tratamento conservador. Entretanto, essa significância se dissipa, tornandose semelhante após 4 anos e igual após 10 anos.

O confronto dos benefícios entre os procedimentos cirúrgico e não cirúrgico foi realizado em estudo prospectivo por Atlas et al., 19965. Embora houvesse sobreposição dos sintomas entre pacientes tratados de modo conservador ou cirúrgico, esses últimos relataram melhora significativa após um ano. Todavia, efeitos sobre o trabalho e compensações empregatícias foram semelhantes nos dois grupos. Não foi observada diferença entre os pacientes submetidos à cirurgia e aqueles com sintomas leves tratados de modo conservador.

Assim sendo, pode-se depreender que a comparação entre os dois tratamentos mantém inalterada a eficácia do método conservador (Zentner et al., 1997; Simotas et al., 2000) ${ }^{69 ; 54}$. Podese mesmo estender o tratamento conservador por mais de 8 semanas, uma vez que muitos pacientes demonstram recuperação progressiva. Essa medida torna-se, portanto, uma aliada adicional no adiamento da cirurgia, que deve ser considerada apenas diante da ineficiência do método conservador (Kurth et al.,1996; Postacchini, 1996; Stevens et al. , 1997) 36;49;56.

Os casos que apresentam absorção completa da hérnia de disco (Basile et al., 1993; Song et al., 1999) ${ }^{8 ; 55}$ reforçam a indicação do tratamento conservador. Do mesmo modo, há resultados positivos desse tratamento (Ahn et al., 2000)2 , com relação à diminuição das hérnias de disco transligamentares (ligamento longitudinal posterior).

Atualmente, diante do novo cenário envolvendo os planos de saúde, todas as cirurgias eletivas de alto custo necessitam ser revistas e a cirurgia de hérnia discal é um exemplo típico (Stevens et al.,1997 $)^{56}$. Segundo Malter \& Weinstein $(1996)^{41}$, os resultados de estudos que relatam a estimativa custo- benefício dessas cirurgias são inconsistentes. Se forem considerados os benefícios a longo prazo, o procedimento cirúrgico não demonstra ser mais efetivo do que o conservador.

A variação de opinião dos especialistas e a falta de uma metodologia sistemática obstruem o desenvolvimento de guias clínicos confiáveis para serem postos em prática. Há a necessidade de serem elaborados protocolos padronizados que quantifiquem, comparem e sumarizem os julgamentos de diferentes especialistas sobre o melhor tratamento a ser adotado (Wietlisbach et al., 1999) ${ }^{66}$.

\section{REFERÊNCIAS}

1. AAOS. American Academy of Orthopaedic Surgeons. Public Information. 1996.

2. Ahn, S. H.; Ahn, M. W.; Byun, W. M. Effect of transligamentous extension of lumbar disc herniations on their regression and the clinical outcome of sciatica. Spine, 25 (4): 475-480, 2000.

3. Annunen, S., Paassilta, P., Lohiniva, J., Perala, M., Pihlayamaa, T., Karppinen, J., Tervonen, O., Kroger, H., Lahde, S., Vanharanta, H., Ryhanen, L., Goring, H.H., Ott, J., Prockop, D.J., Ala-Kokko, L. An allele of COL9A2 associated with intervertebral disc disease. Science 285: 409-412, 1999.

4. Atlas, S.J., Chang, Y., Kammann, E., Keller, R.B., Deyo, R.A., Singer, D.E. Long term disability and return to work among patients who have a herniated lumbar disc: the effect of disability compensation. J Bone Joint Surg Am 82: 4-15, 2000.

5. Atlas, S.J., Deyo, R.A., Keller, R.B., Chapin, A.M., Patrick, D.L., Long, J.M., Singer, D.E. The main lumbar spine study, part II. 1-year outcomes of surgical and non-surgical management of sciatica. Spine 21:1777-1786, 1996.

6. Bach, M. Psychosomatic aspects of chronic low back pain. Anathesiol Intensivmed Notfallmed Schmerzther 33: 802-806, 1998.

7. Barros $F^{\circ}$, T. \& Basile Jr., R. Coluna vertebral. Diagnóstico e Tatamento das Principais Patologias. Sarvier Editora, São Paulo, 1995, p.59-75.

8. Basile Jr.,R.; Rosemberg, L.; Barros $F^{\circ}$, T. \& Bonetti, C. Absorção da hérnia do núcleo pulposo lombar. Acta Ortop. Bras.1:127-130, 1993.

9. Battie, M.C., Haynor, D.R., Fisher, L.D., Gill, K., Gibbons, L.E., Videman, T. Similarities in degenerative findings on magnetic resonance images of the lumbar spines of identical twins. J Bone Joint Surg Am 77: 1662-1670, 1995 a .

10. Battie, M.C., Videman, T., Gibbons, L.E., Fisher, L.D., Manninen, H., Gill, K. 1995 Volvo Award in Clinical Sciences. Determinants of lumbar disc degeneration. A study relating lifetime exposures and magnetic resonance findings in identical twins. Spine 20: 2601-2612, 1995b.

11. Bell, G. \& Rothman, R. The conservative treatment of sciatica. Spine.9: 54-56, 1984.

12. Bergmann, T. F. \& Jongeward, B. V. Manipulative therapy in lower back pain with leg pain and neurologic deficit. J Manipulative Physiol Ther 21: 288-294, 1998.

13. Bessette, L., Liang, M. H., Lew, R. A., Weinstein, J. N. Classics in spine. Surgery literature revisited. Spine 21: 259-263, 1996.

14. Borenstein, D. G. Medical therapy of low back pain. Orthop Rev 22: 20-25, 1993.

15. Borenstein, D. G. A clinician's approach to acute low back pain. Am J Med 102: 16S- 22S, 1997.

16. Bortoletto, A.; Prata, S. \& Bonfim dos Santos, G. Hérnia discal em crianças e adolescentes: relato de cinco casos. Rev. Bras. Orto. 33: 811-814, 1998.

17. Bratton, R. L. Assessment and management of acute low back pain. Am Fam Physician 60: 2299-2308, 1999.

18. Bullock, M.L., Pheley. A .M., Lenz, S.K., Culliton, P.D. Short-term outcomes of treatment for musculo-skeletal disorders in a hospital-based alternative and complementary medicine clinic. J Altern Complement Med 5: 253-260, 1999.

19. Christensen, T.H.; Bhiddal, H.; Hansen, S. E.; Jensen, H.; Jensen, R. \& Bay, H. Severe low-back pain. Scand J. Rheumatol. 22: 25-29, 1993.

20. Cortet, B. \& Bourgeois, P. Causes and mechanisms of sciatica pains. Ver Prat 42: 539-543, 1992.

21. Della- Giustina, D. A. Emergency department evaluation and treatment of back pain. Emerg Med Clin North Am 17: 877-893, 1999.

22. Deyo, R. Conservative therapy for low back pain. JAMA 250: 1057-1062, 1983.

23. Doege, K.J., Coulter, S. N., Meek, L. M., Maslen, K., Wood, J. G. A human-specific polymorphism in the codon region of the aggrecan gene. J Biol Chem 272: 1397413979, 1997

24. Ernst, E., Fialka, V. Conservative therapy of low back pain. Part 1: Immobilization. Fortschr Med 111: 311-312, 1993a.

25. Ernst, E., Fialka, V. Conservative therapy of low back pain. Part 2: Drug therapy of low back pain. Fortschr Med 111: 329-331, 1993b.

26. Fiechtner, J. J. \& Brodeur, R. R. Manual and manipulation techniques for rheumatic disease. Rheum Dis Clin North Am 26: 83-96, 2000.

27. Garrido, E. Lumbar disc herniation in the pediatric patient. Neurosurg Clin N Am 4:149-152, 1993.

28. Herno, A ., Airaksinen, O ., Saari, T., Luukkonen, M. Lumbar spinal stenosis: a matched-pair study of operated and non-operated patients. Br J Neurosurg 10: 461-465, 1996. 
29. Hopayian, K., Mygford, M. Conflicting conclusions from two systematic reviews of epidural injections for sciatica : which evidence should general practitioners heed? Br J Gen Pract 49: 57-61, 1999.

30. Horton, W. E., Lethbridge-Cejku, M., Hochberg, M. C., Balakir, R., Precht, P., Tobin, J D., Meek, L., Doege, K. An association between an aggrecan gene polymorphic allele and bilateral hand osteoarthritis in elderly white men: data from the Baltimore Longitudinal Study of Aging (BLSA). Osteoarthritis Cartilage 6: 245-251, 1998.

31. Jones, G., White, C., Sambrook, P., Eisman, J. Allelic variation in the vitamin D receptor lifestyle factors and lumbar spinal degenerative disease. Ann Rheum Dis 57: 9499, 1998.

32. Kakelius, A. Prognosis in sciatica. A clinical follow-up of surgical and non-surgical treatment. Acta Orthopaedica Scandinavica, Suppl. 129, 1970, 76p.

33. Kawaguchi, Y., Osada, R., Kanamori, M., Ishihara, H., Ohmori, K., Matsui, H., Kimura, T. Association between an aggrecan gene polymorphism and lumbar disc degeneration. Spine 24: 2456-2460, 1999.

34. Komori, H., Otaiva, A; Haro, H. \& Shinomiya, K. Contrast-enhanced magnetic resonance imaging in conservative management of lumbar disc herniation. Spine 23: $67-73,1998$

35. Komori, H.; Shinomiya, K.; Nakai, O.; Yamaura, I. \& Furuya, K. The natural history of herniated nucleus pulposus with radiculopathy. Spine 21: 225-229, 1996.

36. Kurth, A . A., Rau, S., Wang, C., Schmitt, E. Treatment of lumbar disc herniation in the second decade of life. Eur Spine J 5: 220-224, 1996.

37. Long, D. M., BenDebba, M., Torgerson, W.S, Boyd, R.J., Dawson, E.G., Hardy, R.W. Robertson, J.T., Sypert, G.W., Watts, C. Persistent back pain and sciatica in the United States: patient characteristics. J Spinal Disord 9: 40-58, 1996.

38. Longworth, W., Mc Carthy, P.W. A review of research on acupunture for the treatment of lumbar disk protrusions and associated neurological symptomatology. J Altern Complement Med 3: 55-76, 1997

39. Lutz, G.K., Butzlaff, M.E., Atlas, S.J., Keller, R.B., Singer, D.E., Deyo, R.A. The relation between expectations and outcomes in surgery for sciatica. J Gen Intern Med 14 740-744, 1999

40. Magnaes, B. Surgical treatment of low back pain. Tidsskr Nor Laegeforen 119: 1773-1777, 1999

41. Malter, A.D., Weintein, J. Cost-effectiveness of lumbar discectomy. Spine 21: 69S74S, 1996

42. Mannion, A . F., Muntener, M. Taimela, S., Dvorak, J. A randomized clinical trial of three active therapies for chronic low back pain. Spine 24: 2435-2438, 1999.

43. Matsui, H, Terahata, N., Tsuji, H., Hirano, N., Naruse, Y. Familial predisposition and clustering for juvenile lumbar disc herniation. Spine 17: 1323-1328, 1992.

44. Matsui, H., Kanamori, M., Ishihara, H., Yudoh, K. Naruse, Y. Isuji, H. Familia predisposition for lumbar degenerative disc disease. Spine 23: 1029-1034, 1998.

45. Mayer, H.M., Mellerowicz, H., Dihlmann, S.W. Endoscopic discectomy in pediatric and juvenile lumbar disc herniations. J Pediatr Orthop B 5: 39-43, 1996.

46. Medrick-Goldberg, T., Lifschitz, D., Pud, D., Adler, R., Eisenberg, E. Intravenous lidocaine, amantadine, and placebo in the treatment of sciatica: a double-blind, randomized, controlled study. Reg Anesth Pain Med 24: 534-540, 1999.

47. Obukhov, S.K., Hankenson, L., Manka, M., Mawk, J.R. Multilevel lumbar disc herniation in 12-year old twins. Childs Nerv Syst 12: 169-171, 1996.

48. Palazzo, E. \& Kahn, M. F. Traitements non chirurgique des sciatiques discales. Rev. Prat. 42: 573-578, 1992

49. Postacchini, F. Results of surgery compared with conservative management for lumbar disc herniations. Spine 21: 1383-1387, 1996.

50. Revel, M. Current therapeutic options in sciatica caused by disc herniation. Ver Med Interne 15: 135-143, 1994

51. Sambrook, P.N., Mac Gregor, A.J., Spector, T. D. Genetic influences on cervical and lumbar disc degeneration : a magnetic resonance imaging study in twins. Arthritis Rheum 42: 366-372, 1999.

52. Scarpinelli, R. Lumbar disc herniation in eight siblings with a possible family history for disc disease. Acta Orthop Belg 59: 371-376, 1993.

53. Schiltenwolf, M. Aspects of conservative pain therapy. Orthopade 28: 966-974, 1999.

54. Simotas. A. C., Dorey, F. J., Hansraj, K. K., Cammisa, FJr. Nonoperative treatment for lumbar spinal stenosis. Clinical and outcome results and a 3-year survivorship analysis. Spine 25: 197-203, 2000

55. Song, J. H.; Park, H. K.; Shin, K. M. Spontaneous regression of a herniated cervical disc in a patient with myelopathy. Case report. J. Neurosurg, 90 (1): 138-140, 1999.
56. Stevens, C.D., Dubois, R.W., Larequi- Lauber, T., Vader, J.P. Efficacy of lumbar discectomy and percutaneous treatments for lumbar disc herniation. Soz Praventivmed 42: 367-379, 1997.

57. Ulreich, A ., Kullich, W. No title. Wien Med Wochenschr 149: 564- 566, 1999.

58. Urban, J.P., Roberts, S. Development and degeneration of the inter-vertebral discs. Mol Med Today 1: 329-335, 1995

59. Varlotta, G.P., Brown, M.D., Kelsey, J.L., Golden, A .L. Familial predisposition for herniation of a lumbar disc in patients who are less than twenty-one years old. $J$ Bone Joint Surg Am 73: 124-128,1991.

60. Videman, T., Leppavuori, J., Kaprio, J., Battie, M.C., Gibbons, L.E., Peltonen, L. Koskenvuo, M. Intragenic polymorphisms of the vitamin D receptor gene associated with inter-vertebral disc degeneration. Spine 23: 2477-2485, 1998.

61. Viton, J. M., Rubino, T., Peretti- Viton, P, Bouvenot, G., Delarque, A . Short-term evaluation of periradicular corticosteroid injections in the treatment of lumbar radiculopathy associated with disc disease. Ver Rhum Engl Ed 65: 195-200, 1998.

62. Vroomen, P.C., de Krom, M.C., Wilmink, J.T., Kester, A .D., Knottnerus, J.A . Lack of effectiveness of bed rest for sciatica. N. Engl J Med 340: 418-423, 1999.

63. Waddell, G. Biopsychosocial analysis of low back pain. Baillieres Clin Rheumatol 6: 523-557, 1992

64. Weber, H. Lumbar disc Herniation. A controlled, prospective study with ten years of observation. Spine 9: 131-140, 1983.

65. Weber, $\mathrm{H}$. The natural history of disc herniation and the influence of intervention Spine 19: 2234-2238, 1994

66. Wietlisbach, V. Vader, J.P., Porchet, F., Costanza, M.C., Burnand, B. Statistical approaches in the development of clinical practice guidelines from expert panels: the case of laminectomy in sciatica patients. Med Care 37: 785-797, 1999.

67. Yamamura, Y.; Cricenti, S., Tabosa, A \& Puertas, D. Importância da inervação micro e macroscópica da coluna lombar para o tratamento, pela acupuntura, das lombalgias. Acta Ortopédica Brasileira 3: 155-160, 1995.

68. Young, J. L., Press, J. M., Herring, S. A. The disc at risk in athletes: perspectives on operative and non-operative care. Med Sci Sports Exerc 29: 222-232, 1997.

69. Zentner, J.; Scheneider, B. \& Schramm, J. Efficacy of conservative treatment of lumbar disc herniation. Journal of Neurosurgical Sciences 41: 263-268, 1997. 